\title{
CREDIT DELIVERY FOR AGRO-ENTREPRENEURSHIP: IMPLICATIONS FOR THE GROWTH OF THE AGRICULTURAL SECTOR IN NIGERIA
}

\author{
Ellis I. Idemobi
}

Chukwuemeka Odumegwu Ojukwu University, Igbariam Campus

\&

\section{Peter N. Ofili}

Delta State Polytechnic, Ogwashi-Uku

\begin{abstract}
The main objective of this study is to ascertain the effect entrepreneurship development through credit delivery on the growth agricultural sector of the Nigerian economy. The specific objectives are to ascertain the effect of credit facilities for cash crop production on Agricultural sector; to determine the effect of credit facilities for livestock production on the growth of the agricultural sector; and to determine the extent to which credit facilities for fisheries affect the sector of the economy. The research is a co-relational study which seeks to examine the relationship between entrepreneurship development and the growth of agricultural sector of the Nigerian economy. The data was collected and analysed using the least square linear regression. The results reveal that that credit delivery for livestock farming have positive and significant effect on the growth of agricultural sector. Credit facilities on cash crop farming shows a negative effect on the growth of agricultural sector, while that of fish farming was found not to have significant effect on the growth of agricultural sector. It is therefore recommended that more money be pumped into the cash crop farming so as to boost the agricultural sector in particular and the Nigerian economy in general.
\end{abstract}

\section{Introduction}

The importance of entrepreneurship for achieving economic growth in any economy cannot be over emphasized. The high rate of unemployment in Nigeria has over some decades now caused a renewed interest in re-evaluation of the role of small firms and a renewed attention to entrepreneurship. This has caused a paradigm shift from capital intensive, large-scale enterprises to small and medium scale Enterprises (SMEs) especially in Agriculture. SMEs apart from having the potentials for ensuring a self-reliant industrial development, in terms of ability to depend on local raw materials, also generate more employment per unit of investment and guarantee an even industrial development, including the rural areas.

Several entrepreneurship development strategies have been ongoing for some decades now, both at federal, state, and local government levels. Some focus more on some are on skill acquisition and others on entrepreneurship financing. Entrepreneurship financing through credit delivery is seen to be one of the most important aspect of entrepreneurship development. This is because of the fact that finance has become a major problem in business start-up in Nigeria, as average entrepreneur in Nigeria is poor and need some financial leverage to start his/her business. Obasanjo (2014) is of the opinion that Nigeria needs to spend much more on agriculture than its current expenditure. He noted that Agricultural Programmes in Nigeria is already proving its potential to produce a dramatic turnaround that sets an example for other African countries. This study therefore is aimed at determining the impact of agroentrepreneurship development through credit delivery on the growth of agricultural sector. 
In Nigeria, the high rate of unemployment has necessitated the call for entrepreneurial development in recent decades. This however has taken different forms such as skill acquisition programs aimed at creating sustainable manpower, giving credit facilities to upcoming entrepreneurs as well as the unemployed and subsidizing raw materials in order to reduce cost of production and hence increasing profit. All these are aimed at improving and strengthening the entrepreneurial base of the economy and to boost the gross domestic product (GDP) of the nation. The most important of them is the credit facilities granted, especially for cash crop, livestock, food crops and fisheries, as most people who have interest in agricultural activity are limited my funds. Since land and other factors can easily come by.

Naudé (2010) argues that the theoretical and empirical cases for understanding the role of entrepreneurship are not yet solid, that evidence on whether entrepreneurship matters for economic growth is not straightforward; that how entrepreneurship has been promoted and how it contributed to development in countries like China and the East Asian Tigers is still a matter of contention. A closer look at the relationship between entrepreneurship and economic development is therefore needed. This study therefore is aimed at determining the impact of entrepreneurship development through credit delivery on the growth of agricultural sector. The main objective of this study is to ascertain the effect entrepreneurship development through credit delivery on the growth agricultural sector of the Nigerian economy. The specific objectives are to (i) ascertain the effect of credit facilities for cash crop production on Agricultural sector; (ii) determine the effect of credit facilities for livestock production on the growth of agricultural sector; and (iii) determine the extent to which credit facilities for fisheries affects the sector of the economy.

\section{Literature Review}

This study adopts the Schumpeter's Theory of the Long Wave (Schumpeter, 1961). "Schumpeter concept of long waves is seen as disturbances in the equilibrium of any economic system, the exhaustion of these disturbances, as well as an eventual return to equilibrium. It is this repeated return to a state of equilibrium that which gives long waves their cyclical character. This state of equilibrium was referred to by Schumpeter as "the circular flow of economic life" or just the "stationary flow". This state refers to a condition comparable to simple reproduction and characterized by an absence of any change or development. But Schumpeter is also explicit that this "stationary flow" is only a theoretical norm, not a real state of affairs: it serves as a reference point from which to define phenomena such as overproduction, excess capacity, and unemployment" (Schumpeter 1961).

The role of entrepreneurship as the driving force of economic growth found its most explicit foundation in Joseph Schumpeter's theory of long waves. According to Schumpeter, "Everyone is an entrepreneur when he actually carries out new combinations". Finding new combinations of factors of production is a process of entrepreneurial discovery that will become the engine that drives economic development. These 'new combinations' constitute better ways to meet create new products or existing demand. The innovative entrepreneur will, accordingly, grow through the dual process of increasing overall demand for the products offered in the market and taking market share from existing suppliers. The importance of entrepreneurship development on the growth of a nation's economy cannot be over emphasized. Several studies have been conducted in these areas although few of them in Nigeria. This review highlight some of the empirical studies done in the areas of entrepreneurship and economic growth. 
Oyelola et al (2013) study underscores the importance of entrepreneurship as a realistic mechanism for sustainable economic growth in Nigeria considering the experiences of developed nations like the US and vibrant economies like China and India. Their paper discussed that entrepreneurship has been instrumental in economic growth, balanced regional development, and job creation in most dynamic economies, where technology is changing at a faster rate and the product lifetime cycle is shrinking. Their paper reveals that the right business environment for entrepreneurship is lacking in Nigeria on account of the challenges of frequent power outages, bad roads, multiple taxes extortion of money from SMEs by government officials, lack of genuine support service for SMEs and expensive transportation/telecommunications costs have all combined to inhibit entrepreneurship and economic growth. They therefore concluded that government should focus on capacity building, improving infrastructure, judicious utilization of the oil wealth and enabling environment thereby leading to sustainable economic growth.

Ghani, Kerr \& O'Connell (2013) analysed the spatial determinants of entrepreneurship in India in the manufacturing and services sectors. Among general district traits, quality of physical infrastructure and workforce education are the strongest predictors of entry, with labour laws and household banking access also playing important roles. They found extensive evidence of agglomeration economies among manufacturing industries. In particular, supportive incumbent industrial structures for input and output markets are strongly linked to higher establishment entry rates. In comparison to the U.S., regional conditions in India play a stronger relative role for the spatial patterns of entrepreneurship compared to incumbent industry locations.

On entrepreneurship financing, Akinola (2013) argued that the roles of entrepreneurship are worldly acclaimed but yet as laudable as these roles there can be no significant success by any entrepreneur except with availability of finance. Nevertheless, mere availability of finance also cannot guarantee the success of an enterprise but there must be in place appropriate financial strategies for the funding/investment needs of an enterprise.

Chinoye (2008) traced Lack of capital for execution of projects/business ventures to industrial era of 18th century when inventors attempted to produce or turn their invention into products in commercial quantities but which lack of finance hampered. The author further observed this to be the beginning of separation of users of capital from providers of capital.

Eigbiremolen \& Anaduaka (2014) employed the augmented Solow human-capital-growth model to investigate the impact of human capital development on national output, a proxy for economic growth, using quarterly time- series data from 1999-2012. Their findings show that human capital exhibits significant positive impact on output level. The results also reveal a relatively inelastic relationship between human capital development and output level. They recommended that government and policy makers should make concerted and sincere efforts in building and developing human capacity through adequate educational funding across all levels.

Maghsoudi \& Davodi (2011) studies the Small and Medium Enterprises as a veritable tool in Economic Growth and Development. Data from 200 SME/Entrepreneurial officers and Managers from five selected local government in Nigeria were collected with a structured questionnaire and analysed with descriptive statistics to identify the perception of the roles of SMEs in Nigeria. The results of their study reveal that the most common constraints hindering entrepreneurship growth in Nigeria are lack of financial support, poor management, corruption, 
lack of training and experience, poor infrastructure, insufficient profits, and low demand for product and services. They therefore recommend that Government should as matter of urgency assist prospective entrepreneurs to have access to finance and necessary information relating to business opportunities, modern technology, raw materials, market, plant and machinery.

Maghsoudi \& Davodi (2011) identified strategies for developing entrepreneurship in agriculture cooperatives and their classification based on the current circumstance. Their population of study was the active agriculture cooperatives managers in Khuzestan province. On evaluation of the entrepreneurship development strategies in the cooperatives, respondents believe that training and developing skills were the effective strategies for developing entrepreneurship in agricultural cooperatives. The result also found that the existing cooperative structure does not provide needed motivation for entrepreneurship. According to interactions between cooperatives, taking patterns from other cooperative is a practical strategy to develop creative plans. Adopted strategies should be formed based on their accessibility level. Factor analyses show that educational - motivational, investing - innovative, supportive, partnership and infrastructure factors explain around 57.3 percent of the factors affecting the development of entrepreneurship in agriculture production cooperatives.

Ascher (2012) discusses the rise of the female entrepreneurship phenomenon, arguing that women entrepreneurship needs to be studied as a separate field for two main reasons: Female entrepreneurship is an important source of economic growth in creating new jobs and by being genetically different; and female entrepreneurship has been neglected, particularly in business research. The author noted that although, equal opportunity for men and women in the entrepreneurial field is not a reality in the short range, the progress towards its achievement could be facilitated by better understanding of the impact of female entrepreneurship on society and its contribution to economic growth. The study, therefore, addresses the growth in female entrepreneurship in the developed and developing countries, explores primary motivational and other factors that influence female entrepreneurship and reviews the main obstacles facing the female entrepreneur.

Abdulquadri \& Mohammed (2012) critically examined the relevance and contribution of agricultural mechanization to the development of the agricultural sector of the economy, and discussed the benefits of credit for agricultural mechanization, and discusses the roles of cooperatives in agricultural mechanization. They found that the cooperative approach is one of the best means of self-protection for small farmers mainly due to its self-help concept and member's participation.

Nwibo \& Okorie (2013) studied role entrepreneurs' play in the development of any economy, as there seems to exist a dearth of empirical knowledge on what constrains entrepreneurs in taking effective entrepreneurial and investment decisions in Southeast Nigeria. They employed a combination of purposive and multistage sampling techniques in the selection of 360 agribusiness investors in the study area. Data were collected primarily using structured questionnaire and interview schedule. Data were analysed using descriptive and inferential statistics. Their result reveals that lack of start-up capital, lack of market information, crime, theft and social disorder, corruption and bad legal system, poor infrastructural facilities, multiple taxation, tedious registration and licensing procedure, and poor access to formal credit facilities were the main constraints to entrepreneurship and investment decisions by agribusiness entrepreneurs in South-East, Nigeria; their result also showed that starting enterprises without proper feasibility, high taxation, inadequate supply of power, inconsistency 
in government policy, inability to withstand competition, management inexperience, poor knowledge in the line of business, and joint ownership of enterprises were the major causes of enterprise failure in Southeast Nigeria.

\section{Methodology}

The research is a correlational study which seeks the relationship between entrepreneurship development and the growth of agricultural sector of the Nigerian economy. The data were secondary in nature. They were data on credit facilities granted for cash crop, livestock and fisheries farming in Nigeria between 1984 to 2013. The data were obtained from the Central bank of Nigeria statistics bulletin 2015 and analysed using the least square linear regression to fit the relationship between entrepreneurship development and the growth of the agricultural sector.

\section{Model Formulation}

The model of the relationship between credit facilities and entrepreneurship development is presented below. The gross domestic product (GDP) for the agricultural sector is the dependent variable and used as a proxy for measuring the growth of the agricultural sector, while the credit facility for cash crop, livestock and fisheries production is the independent variable. The model is given as:

Agric_GDP $=f($ credit facilities $)$

Hence, Agric GDP $=\alpha_{01}+\alpha_{1}$ Cash_crop $+\alpha_{2}$ Livestoch $+\alpha_{3}$ Fisheries $+E$

Where, Agric_GDP = GDP of agricultural sector

$\alpha_{01}$ is the intercept of the regression model for the relationship between credit facilities and growth of agricultural sector.

$\alpha_{1}, \alpha_{2}$ and $\alpha_{3}$ are rates of change (slope) of Agric_GDP with respect to cash crop, livestock and fisheries respectively.

Cash_crop is the credit facilities given for cash crop farming.

Livestock is the credit facilities given for livestock farming.

Fisheries is the credit facilities given for fish farming.

$\mathrm{E}=$ error term

The following hypothesis are formulated in this study:

1. $\mathrm{H}_{0}$ : credit facilities for cash crop production do not have significant relationship with the growth of agricultural sector.

$\mathrm{H}_{\mathrm{a}}$ : credit facilities for cash crop production have significant relationship with the growth of agricultural sector

2. $\mathrm{H}_{0}$ : credit facilities for livestock production have no significant relationship with the growth of the agricultural sector.

$\mathrm{H}_{\mathrm{a}}$ : credit facilities for livestock production have significant relationship with the growth of the agricultural sector

3. $\mathrm{H}_{0}$ : credit facilities for fisheries does not have significant effect on the agricultural sector of the economy.

$\mathrm{H}_{\mathrm{a}}$ : credit facilities for fisheries have effect on the agricultural sector of the economy 


\section{Decision Rule}

Reject $\mathrm{H}_{0}$ if the $\mathrm{p}$-value is less than 0.05 and conclude that credit facilities for aa given variable have significant relationship with the growth of agricultural sector. Accept otherwise.

\section{Discussion of Findings}

The result of the hypothesis testing on the effect of entrepreneurship development and the growth of agricultural sector is presented in Table 1 highlighting the correlation coefficient and $\mathrm{R}$-squared value for the hypothesis testing for the relationship between entrepreneurship development and agricultural sector growth. The correlation coefficient of 0.924 shows that a strong positive relationship exists entrepreneurship development and agricultural sector growth and is significant at $5 \%$ level of significance.

\section{Table 1: Model Summary}

\begin{tabular}{|l|l|l|l|l|}
\hline $\begin{array}{l}\text { Mode } \\
1\end{array}$ & $\mathrm{R}$ & R Square & Adjusted R Square & Std. Error of the Estimate \\
\hline 1 & $.924^{\mathrm{a}}$ & .854 & .837 & 35354.48170 \\
\hline
\end{tabular}

\section{a. Predictors: (Constant), Fisheries, Cash_Crop, Livestock}

This value of correlation coefficient means that $92.4 \%$ relationship exist between entrepreneurship development through credit delivery and the growth of agricultural sector. The positive value of the correlation coefficient means that increase in credit facilities leads to corresponding increase in the growth of agricultural sector and vice versa. Also, the R-squared value of 0.854 means that $85.4 \%$ variation in the growth of agricultural sector of the Nigerian economy is attributable to entrepreneurship development through credit delivery.

Table 2 presents the analysis of variance (ANOVA) table for the relationship between entrepreneurship development and agricultural sector growth. The p-value (sig.) of 0.000 shows that the least square linear regression gives the best fit for the relationship between entrepreneurship development and the growth of agricultural sector.

\section{Table 2: ANOVA for the relationship between entrepreneurship development and} agricultural growth

\begin{tabular}{|ll|l|l|l|l|l|}
\hline \multicolumn{2}{|c|}{ Model } & Sum of Squares & df & Mean Square & F & Sig. \\
\hline \multirow{4}{*}{1} & Regression & 190098676535.538 & 3 & 63366225511.846 & 50.695 & $.000^{\mathrm{b}}$ \\
& Residual & 32498423777.733 & 26 & 1249939376.067 & & \\
& Total & 222597100313.271 & 29 & & & \\
\hline
\end{tabular}
a. Dependent Variable: Agric_GDP
b. Predictors: (Constant), Fisheries, Cash_Crop, Livestock

Comparison of the p-values in Table 3 over $0.05(5 \%)$ level of significance shows that credit facilities for cash crop and livestock farming have significant effect on the growth of agricultural sector, while fish farming does not. 
Table 3: Regression Coefficients for the relationship between entrepreneurship development and agricultural growth

\begin{tabular}{|ll|l|l|l|l|l|}
\hline \multicolumn{2}{|l|}{ Model } & \multicolumn{2}{l|l|}{$\begin{array}{l}\text { Unstandardized } \\
\text { Coefficients }\end{array}$} & $\begin{array}{l}\text { Standardized } \\
\text { Coefficients }\end{array}$ & \multirow{2}{*}{ Sig. } \\
\cline { 3 - 5 } & $\mathrm{B}$ & Std. Error & Beta & & \\
\hline \multirow{4}{*}{1} & (Constant) & 128081.192 & 8621.157 & & 14.857 & .000 \\
& Cash_Crop & -4.177 & .931 & -3.820 & -4.488 & .000 \\
& Livestock & .824 & .161 & 4.466 & 5.132 & .000 \\
& Fisheries & .061 & .043 & .217 & 1.402 & .173 \\
\hline
\end{tabular}

a. Dependent Variable: Agric_GDP

Credit delivery on cash crop farming was found to have inverse relationship on the growth of the agricultural sector as the regression coefficient has negative sign. Credit facilities given for livestock farming was found to have positive effect on the growth of the agricultural sector.

\section{Conclusions}

The results of the hypothesis have been presented. The results show that credit delivery for livestock farming have positive and significant effect on the growth of agricultural sector. Credit facilities on cash crop farming shows a negative effect on the growth of agricultural sector, while that of fish farming was found not to have significant effect on the growth of agricultural sector. These lead to the conclusion that not all aspects of entrepreneurship development have significant effect on the growth of agricultural sector. The insignificant effect of credit facilities to fish farming may be because most of the fish farmer are at a very small and micro levels, as such may not easily be accounted for. Again, the negative effect of credit facilities to cash crop farming suggests that cash crop farming may not have had enough credit support, thus making the already credit facilities insignificant. It is therefore recommended that more money be pumped into the cash crop farming so as to boost the agricultural sector in particular and the Nigerian economy in general.

\section{References}

Abdulquadri, A.F. \& Mohammed, B.T. (2012). The Role of Agricultural Cooperatives in Agricultural Mechanization in Nigeria. World Journal of Agricultural Sciences, 8(5), 537-539

Akinola, A. O (2013). Entrepreneurship in Nigeria-Funding and Financing Strategies, European Journal of Accounting Auditing and Finance ResearchVol.1(4), pp.115-128

Ascher, J. (2012). Female entrepreneurship-An appropriate response to gender discrimination. Journal of Entrepreneurship, Management and Innovation, 8(4), 97114.

Ghani, E., Kerr, W. R., \& O'Connell, S. (2014). Spatial determinants of entrepreneurship in India. Regional Studies, 48(6), 1071-1089.

Maghsoudi, T. \& Davodi, H. (2011). Entrepreneurship Development Strategies in Agriculture Cooperatives in Iran. American-Eurasian J. Agric. \& Environ. Sci., 10 (2): 283-289.

Naudé, W. (2013) Entrepreneurship and Economic Development: Theory, Evidence and Policy. IZA Discussion Paper No. 7507

Nwibo, S. U \& Okorie, A. (2013). Constraints to Entrepreneurship and Investment Decisions among Agribusiness Investors in Southeast, Nigeria. International Journal of Small Business and Entrepreneurship Research,1(4), pp.38-50. 
Obasanjo, O (2014). In Nigeria, Agriculture Is 'The New Oil', Guest commentary curated by ForbesOpinion. Avik Roy, Opinion Editor. https://www.forbes.com/sites/realspin/2014/05/14/in-nigeria-agriculture-is-the-newoil/\#5e03b11d5e03

Oyelola, O. T., Ajiboshin, I. O., Raimi, L., Raheem, S., Igwe, .C. N. (2013). Entrepreneurship for Sustainable Economic Growth in Nigeria. Journal of Sustainable Development Studies, 2(2) pp.197-215

Schumpeter, J. (1961). Theory of Economic Development. Cambridge, Mass: Harvard University Press. 
APPENDIX

Data on credit facilities to various sub sectors and the agric. GDP

\begin{tabular}{|c|c|c|c|c|}
\hline Year & $\begin{array}{l}\text { Cash Crop } \\
(\$ 000)\end{array}$ & $\begin{array}{l}\text { Livestock } \\
(\equiv 000)\end{array}$ & $\begin{array}{l}\text { Fisheries } \\
\text { ( } 000)\end{array}$ & $\begin{array}{lll}\begin{array}{l}\text { Agric } \\
\underline{6000})\end{array} & \text { GDP } & (\mathbf{N} \\
\end{array}$ \\
\hline 1984 & $2,511.90$ & $11,816.50$ & 826.00 & $55,918.17$ \\
\hline 1985 & $6,050.70$ & $14,158.50$ & 718.10 & $65,748.44$ \\
\hline 1986 & $7,659.20$ & $25,804.40$ & $1,644.70$ & $72,135.23$ \\
\hline 1987 & $13,790.30$ & $29,387.90$ & $4,526.30$ & $69,608.06$ \\
\hline 1988 & $19,886.10$ & $18,480.40$ & $4,536.80$ & $76,753.72$ \\
\hline 1989 & $15,539.20$ & $7,874.60$ & $4,538.70$ & $80,878.04$ \\
\hline 1990 & $8,986.30$ & $4,967.30$ & $3,900.70$ & $84,344.61$ \\
\hline 1991 & $6,460.20$ & $4,446.90$ & $1,698.20$ & $87,503.53$ \\
\hline 1992 & $6,423.20$ & $6,056.10$ & $1,038.70$ & $89,345.43$ \\
\hline 1993 & $2,384.90$ & $5,505.80$ & 428.00 & $90,596.51$ \\
\hline 1994 & $8,094.40$ & $10,527.90$ & $2,438.00$ & $92,832.95$ \\
\hline 1995 & $13,499.30$ & $18,048.50$ & $1,512.00$ & $96,220.67$ \\
\hline 1996 & $15,176.00$ & $28,216.90$ & $2,145.00$ & $100,216.18$ \\
\hline 1997 & $13,755.50$ & $23,404.70$ & $3,554.50$ & $104,514.00$ \\
\hline 1998 & $7,197.10$ & $22,587.10$ & $3,456.00$ & $108,814.07$ \\
\hline 1999 & $4,920.00$ & $11,952.00$ & $6,180.00$ & $114,570.71$ \\
\hline 2000 & $4,928.00$ & $27,307.00$ & 899.00 & $117,945.07$ \\
\hline 2001 & $17,169.00$ & $60,415.70$ & $15,742.20$ & $122,522.34$ \\
\hline 2002 & $13,214.40$ & $64,449.60$ & $12,069.30$ & $190,133.40$ \\
\hline 2003 & $10,961.00$ & $100,486.40$ & $13,050.00$ & $203,409.87$ \\
\hline 2004 & $18,185.00$ & $190,304.00$ & $18,240.00$ & $216,208.47$ \\
\hline 2005 & $154,830.00$ & $844,882.80$ & $262,195.00$ & $231,463.61$ \\
\hline 2006 & $67,165.00$ & $368,151.00$ & $114,400.00$ & $248,598.96$ \\
\hline 2007 & $42,331.00$ & $353,487.25$ & $140,690.00$ & $266,477.18$ \\
\hline 2008 & $190,589.00$ & $1,108,483.82$ & $368,630.00$ & $283,175.43$ \\
\hline 2009 & $298,367.80$ & $1,725,801.27$ & $708,621.24$ & $299,996.90$ \\
\hline 2010 & $102,858.20$ & $607,339.98$ & $848,640.00$ & $283,216.50$ \\
\hline 2011 & $197,271.67$ & $1,147,208.36$ & $820,884.00$ & $288,796.28$ \\
\hline 2012 & $199,499.22$ & $1,160,116.54$ & $886,240.00$ & $290,669.89$ \\
\hline 2013 & $166,543.03$ & $971,554.96$ & $895,500.00$ & $287,560.89$ \\
\hline
\end{tabular}

